Diabetologia 10, 625-632 (1974)

(c) by Springer-Verlag 1974

\title{
Diabetes in the Toronto-KK Hybrid Mouse Abnormalities in Liver and Pancreatic Islets of Langerhans
}

\author{
Michael C. Appel, Albert Y. Chang and W.E. Dulin \\ Dept. of Anatomy, University of Minnesota, Minneapolis, Minnesota and Department of Diabetes and Atherosclerosis \\ Research, The Upjohn Company, Kalamazoo, Mich., USA
}

Summary. The activities of six hepatic enzymes were assayed in six-month old Toronto-KK and C57BL/6J mice. Activities of hepatic gluconeogenic enzymes (phosphoenolpyruvate carboxykinase, glucose-6-phosphatase, fructose-1,6-diphosphatase) were significantly elevated in Toronto-KK mice while activities of glycolytic enzymes (glucokinase, hexokinase, pyruvate kinase) remained normal. Isolated islets of Langerhans obtained from Toronto-KK mice demonstrated significantly elevated levels of insulin secretion and of insulin and RNA biosynthesis in response to glucose stimulation. Islets of Toronto-KK mice were markedly hyperplastic and showed pronounced B-cell degranulation after stimulation with glucose. The data suggest that hyperglycemia appears to result, in part, from excessive gluconeogenesis. Hyperinsulinemia appears to result from excessive insulin synthesis and release from the pancreatic islets in response to glucose stimulation.

Key words: Toronto-KK mouse, diabetes in animals, gluconeogenesis, insulin synthesis and secretion, islets of Langerhans, obesity, gluconeogenic enzymes, glycolytic enzymes, B-cell degranulation, islet RNA synthesis.
In an attempt to establish a colony of KK mice displaying greater homogeneity in the expression of diabetic characteristics, a hybrid between the KK mouse and the C57BL/6J mouse has been inbred and designated as the Toronto-KK mouse. The metabolic disorders associated with the diabetic syndrome of this animal are similar to those of the parent $K K$ strain and have been previously described by Nakamura [20, 21], Dulin $[7,8]$ and others $[3,16,19]$. Particularly striking abnormalities associated with diabetes in this animal include hyperglycemia and hyperinsulinemia. At present, the etiological factors responsible for these conditions remain unclear. This paper summarizes our efforts to evaluate the roles of hepatic glycolytic and gluconeogenic enzyme activities and of insulin biosynthetic and secretory components from isolated pancreatic islets of Langerhans on these respective metabolic defects.

\section{Materials and Methods}

\section{Animals}

Toronto-KK mice were obtained from crosses between the Japanese KK mouse and the C57BL/6J mouse (The Jackson Laboratory) [2]. The hybrid progeny resulting from this crossing were maintained in the Upjohn colony [7] and were continuously inbred. Toronto-KK mice were selected on the basis of their fulfilling the following criteria: body weights equal to or greater than $35 \mathrm{~g}$, blood glucose concentration equal to or greater than $200 \mathrm{mg} \%$ and plasma immunoreactive insulin levels equal to or greater than $1000 \mu \mathrm{U} / \mathrm{ml}$. Male animals six months of age were selected because the diabetic characteristics were more uniform in male than in female mice, and the diabetic syndrome appears to be climatic at this stage of development. C57BL/6J mice of the same age and sex served as controls. All animals were provided with food (Purina Mouse Breeder (how) and water ad libitum.

\section{Liver Enzyme Assays}

Liver supernatant and microsomal fractions were prepared as described by Chang et al. [4]. The following enzymes were assayed by methods cited in the references: glucokinase (glukase) - hexokinase (hexkase) [23], pyruvate kinase (pyr-kase) [24], phosphoenolpyruvate carboxykinase (PEP-CK) [26], glucose6-phosphatase (glu-6-Pase) [22] and fructose-1,6diphosphatase (fruct-1,6-dPase) [27]. Inorganic phosphate concentrations were estimated by the method of Nordlie et al. [22].

\section{Insulin Content from Plasma, Pancreas and Isolated Islets of Langerhans}

Blood samples were collected from the orbital venous sinus using heparinized capillary tubes and $0.1 \mathrm{ml}$ plasma was used for the insulin assay. Pancreatic insulin content was determined by processing individual pancreata according to the method of Gerritsen et al. [10] with subsequent insulin assay. Insulin content from isolated islets of Langerhans was determined following sonication of the islets in $0.1 \mathrm{M}$ Tris-Cl buffer ( $\mathrm{pH} 7.4$ ) containing $1 \%$ bovine serum albumin and assaying the sonicate at various dilutions. All insulin concentrations were estimated according to the radioimmunoassay procedure of Zaharko and Beck [30]. 


\section{Insulin Secretion}

Islets of Langerhans were isolated from the intact pancreas using the method of Lacy and Kostianovsky [17]. Fifty islets were transferred to conical Swinex ${ }^{\circledR}$ 13-Filter units (Millipore Corporation) containing a three micron cellulose filter and connected at both ends with Tygone ${ }^{\circledR}$ tubing. Flow of buffer was maintained constant at $2.0 \mathrm{ml} / \mathrm{min}$ by means of a Cole-Parmer Masterflex microperistaltic pump and effluent from the distal portion of the filter unit was recovered using a fraction collector and frozen immediately. A modified Hank's solution ( $\mathrm{pH} 7.4$ ) containing $4.2 \mathrm{mEq} / \mathrm{l} \mathrm{CaCl}_{2}$ $2 \mathrm{H}_{2} \mathrm{O}, 1.0 \mathrm{~g} / \mathrm{l}$ bovine serum albumin, and $2000 \mu \mathrm{U} / \mathrm{l}$ pancreatic trypsin inhibitor either with or without glucose in one of the following concentrations was used as a "perifusate": $0.9 \mathrm{~g} / \mathrm{l}$ glucose or $3.75 \mathrm{~g} / \mathrm{l}$ glucose. The perifusate was maintained at $37^{\circ} \mathrm{C}$ and gassed continuously with $95 \% \mathrm{O}_{2}-5 \% \mathrm{CO}_{2}$. All islets were equilibrated for fifteen minutes in perifusate containing no glucose and subsequently stimulated with respective glucose test solutions for $90 \mathrm{~min}$.

\section{Insulin Biosynthesis}

One hundred islets were isolated from two animals and transferred to a Parafilm ${ }^{\circledR}$ covered watchglass. As a control comparable segments of acinar pancreas were harvested and treated in the same way as the islet tissues. (Hereafter, only treatment of islet tissues is discussed). Isolated islets were incubated in $0.25 \mathrm{ml}$ of medium of the following composition: KrebsRinger bicarbonate buffer ( $\mathrm{pH}$ 7.4) which contained $2 \mu \mathrm{g} / \mathrm{ml} 19$ amino acid mixture (leucine excluded), $3.75 \mathrm{mg} / \mathrm{ml}$ glucose, $1 \mu \mathrm{g} / \mathrm{ml}$ pancreatic trypsin inhibitor, $0.2 \mathrm{mg} / \mathrm{ml}$ bovine serum albumin, $0.9 \mathrm{mM}$ $\mathrm{KH}_{2}$ PO4- ${ }^{32} \mathrm{P}$ (100 mCi/mmole, New England Nuclear) and $5.7 \mu \mathrm{M}$ leucine- ${ }^{3} \mathrm{H}(2.2 \mathrm{mCi} / \mathrm{mmole}$, New England Nuclear). Incubation was allowed to proceed at $37^{\circ} \mathrm{C}$ for four hours under an atmosphere of $95 \% \quad \mathrm{O}_{2}-5 \%$ $\mathrm{CO}_{2}$. At the end of incubation the islets and medium were extracted with $1.0 \mathrm{ml}$ acid alcohol containing $1 \mathrm{mM}$ leucine, $0.118 \mathrm{M} \mathrm{KH}_{2} \mathrm{PO}_{4}$ and $1 \mathrm{mg} / \mathrm{ml}$ bovine insulin (Sigma) as carrier according to Davoren [5]. The precipitates thus obtained were fractionated on a Bio Gel P 30 column $(0.9 \times 60 \mathrm{~cm})$ in $3.0 \mathrm{M}$ acetic acid. The radioactivity of the bovine insulin peak indicated the amount of leucine- ${ }^{3} \mathrm{H}$ incorporation into murine insulin.

\section{$R N A$ and $D N A$}

The precipitate obtained after islet homogenization was washed $5 \times$ with $1 \mathrm{~N} \cdot \mathrm{HClO}_{4}$ containing $1 \mathrm{mM}$ leucine and $0.118 \mathrm{MKH}_{2} \mathrm{PO}_{4} ; 0.91 \mathrm{ml}$ of $0.5 \mathrm{M} \mathrm{NaOH}$ was added to the precipitate and the suspension incubated at $37^{\circ} \mathrm{C}$ for one $\mathrm{h}$. Following incubation, $0.09 \mathrm{ml}$ of $70 \% \mathrm{HClO}_{4}$ was added and the mixture centrifuged. The radioactivity from aliquots of the $0.5 \mathrm{M} \mathrm{NaOH}$ hydrolysate were determined and RNA content was estimated according to Fleck et al. [9]. The precipitate obtained after alkaline hydrolysis was in- cubated in $1.0 \mathrm{ml}$ of $1.0 \mathrm{MHClO}_{4}$ at $90^{\circ} \mathrm{C}$ for $20 \mathrm{~min}$. The mixture was centrifuged and the DNA content of the supernatant estimated according to Tsanev et al. [25].

\section{Miscellaneous}

Tissues prepared for histological demonstration were fixed in Bouin's solution and stained with hematoxylin and eosin [15] and/or with Gormori's aldehyde füchsin-ponceau [11] stain. Blood glucose was determined according to the method of Hoffman [14] and protein determination was performed according to Lowry et al. [18]. Hepatic glycogen was precipitated from $30 \% \mathrm{KOH}$ extract and measured with the phenolsulfuric acid method [6]. Spectrophotometric measurements were performed with a Beckman DB spectrophotometer. Radioactivity determinations were made using a Packard Tricarb Scintillation Spectrophotometer and corrected for quenching using the channelratio method [13].

\section{Results}

\section{General Characteristics}

Various characteristics of Toronto-KK and C57BL/ 6J mice are summarized in Fig. 1. At six months of age, Toronto-KK mice are significantly heavier than controls and are markedly obese as evidenced by the

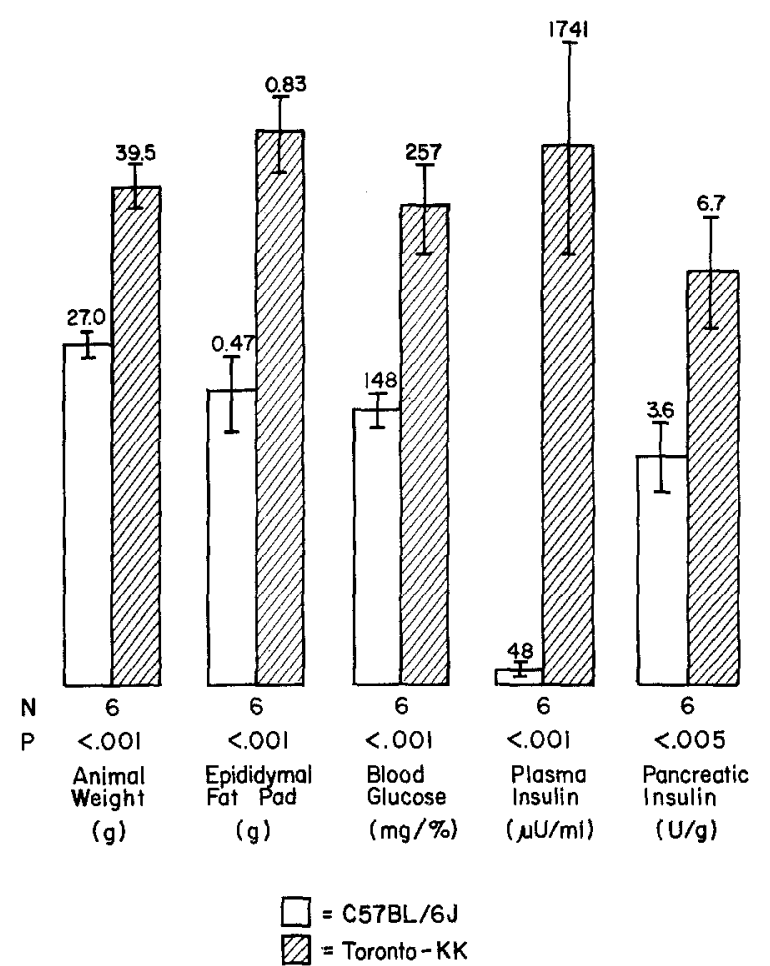

Fig. 1. Various characteristics of six-month old C57BL/6J and Toronto-KK mice. Numbers indicate the mean of results obtained from studies on $\mathrm{N}$ animals 
significantly increased weight of their epididymal fat pads. Non-fasting blood glucose levels were significantly higher than controls and plasma immunoreactive insulin was more than thirty times that of controls. Pancreata of Toronto-KK mice contained nearly twice as much insulin per unit tissue weight as those of the controls.

\section{Liver Studies}

Livers of Toronto-KK mice were greatly enlarged and showed marked fat deposition which in other studies has been identified as "fatty liver" syndrome [1]. Toronto-KK livers weighed more than twice that of control livers, accounted for a significantly greater percentage of total animal body weight and contained significantly less total protein and glycogen per unit tissue weight than the control livers (Fig. 2). The activities of six hepatic "regulatory" enzymes were assayed (Fig. 3). No significant differences were observed in the activities of glycolytic enzymes (glu Kase, hex Kase, pyr Kase) between liver fractions from Toronto-KK and control mice. However, activities of gluconeogenic enzymes (PEP-CK, glu-6-Pase, fruc-1, 6 , d Pase) were significantly elevated in livers from Toronto-KK mice.

\section{Insulin Secretion}

Fig. 4 illustrates the results obtained from typical experiments in which the effects of physiologically "high" and "low" glucose concentrations upon insulin release were studied. The patterns of glucose-induced insulin release were generally similar from islets of both animals. With the absence of glucose in the perifusate, islets from both animals released small and approximately equal amounts of insulin. However, islets from Toronto-KK mice released significantly more insulin than controls when stimulated with either $0.9 \mathrm{~g} / 1$ or $3.75 \mathrm{~g} / \mathrm{l}$ glucose solutions. Insulin release appeared to be multiphasic from islets of both animals as was reported by Grodsky [12]; however, the pattern of multiphasic insulin release was most pronounced from Toronto-KK islets. Table 1 summarizes the results of the insulin studies and shows some quantitative variances between Toronto-KK and C57BL/6J islets. Islets of Langerhans from Toronto-KK mice contained more than twice as much insulin per islet than did control islets either before or after perifusion. Toronto-KK islets also released more than four times as much insulin during the perifusion period than the control islets when stimulated with the same concentrations of glucose. Finally, the percentage of insulin released to total islet insulin from Toronto-KK islets was over twice as much as that from islets of controls.

\section{Insulin Biosynthesis}

The BioGel P 30 elution profile of leucine- ${ }^{3} \mathrm{H}$ labelled acid alcohol soluble proteins may be seen in Fig. 5 . Both C57BL/6J and Toronto-KK islets synthesized insulin in vitro as evidenced by the peak of radioactivity

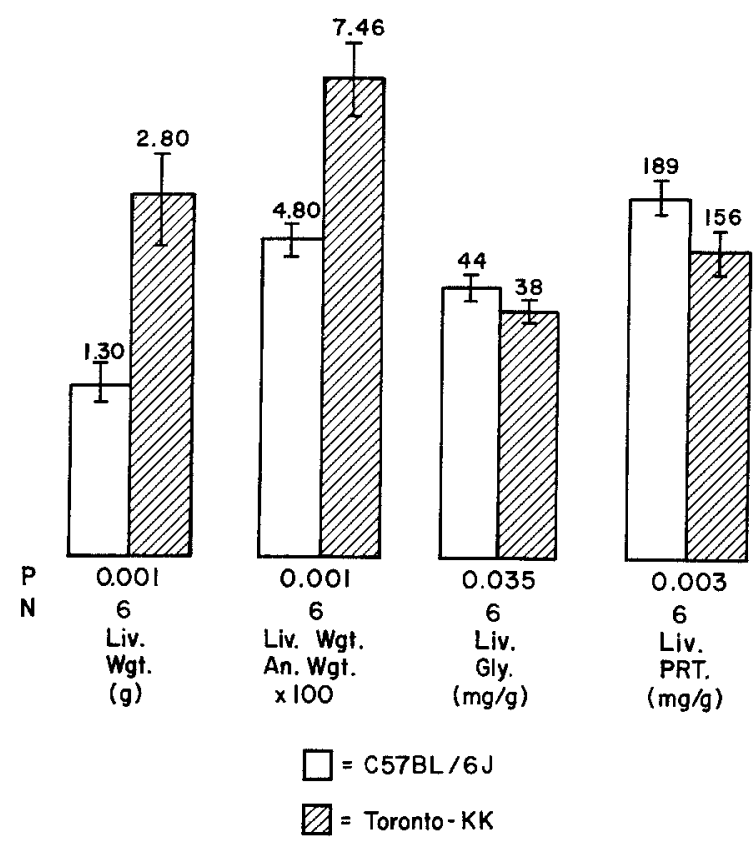

Fig. 2. Various characteristics of livers of six-month old C57BL/6J and Toronto-KK mice

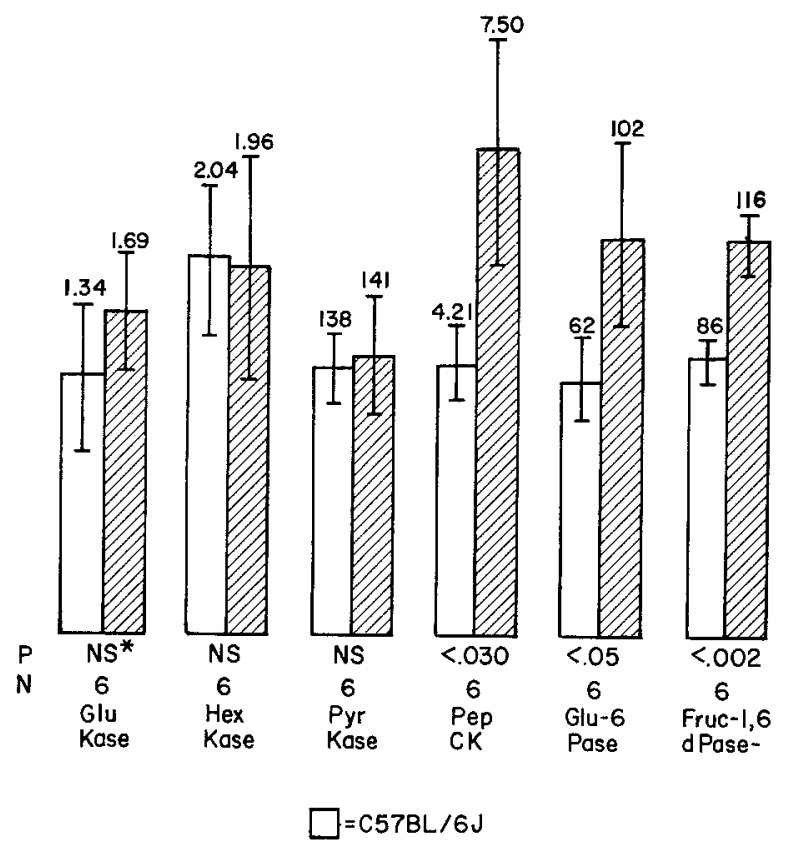

Fig. 3. Activities of the hepatic enzymes of six-month old $\mathrm{C} 57 \mathrm{BL} / 6 \mathrm{~J}$ and Toronto-KK mice. Numbers represent the mean of specific activity of individual enzyme obtained from studies on $\mathrm{N}$ animals. Specific activity was defined as nmole substrate turnover per minute per mg total liver protein 
coincident with the elution position of the bovine insulin carrier. However, greater incorporation of the label occurred in Toronto-KK islets indicating a greater degree of insulin biosynthesis. Peaks corresponding with proinsulin were also evident in both types of islets, with greater incorporation present in Toronto-KK islets. The relative proportions of proinsulin to insulin synthesized during incubation were approximately equal in both animals. No leucine- ${ }^{3} \mathrm{H}$ labelled materials were associated with the elution position of the bovine insulin carrier in any of the acinar tissues studied.
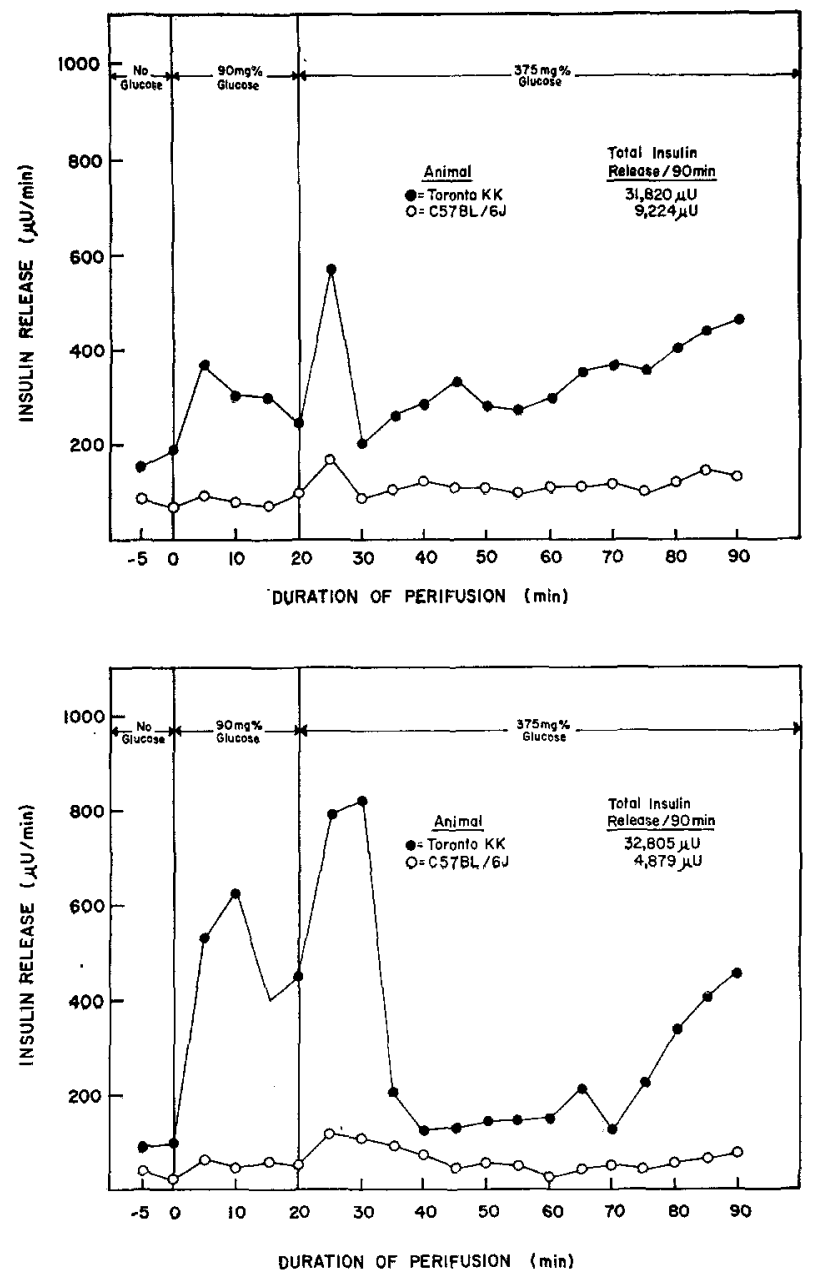

Fig. 4. Insulin release profiles by isolated islets of Langerhans in response to continuous stimulation of glucose

\section{$R N A$ and DNA}

Islets of Langerhans from Toronto-KK mice contained significantly more DNA and RNA than the control islets (Table 2). In addition, both the total incorporation of $\mathrm{KH}_{2} \mathrm{PO}_{4^{-3}}{ }^{32} \mathrm{P}$ into RNA fraction and the specific incorporation of $\mathrm{KH}_{2} \mathrm{PO}_{4}{ }^{32} \mathrm{P}$ (incorporation into RNA fraction per unit weight of islet DNA) were significantly greater from Toronto-KK islets than from controls.

\section{Histological Examination of Pancreatic Islets}

Islets of Langerhans from Toronto-KK mice were markedly hyperplastic (Fig. 6). The ovoid or spherical shape of islets from C57BL/6J mice contrasted sharply with the Toronto-KK islets which appeared frequently as irregularly contoured structures. Large areas of cavitation and occasional blood-filled sinusoids were also observed in Toronto-KK islets. Striking differ-

ACINAR

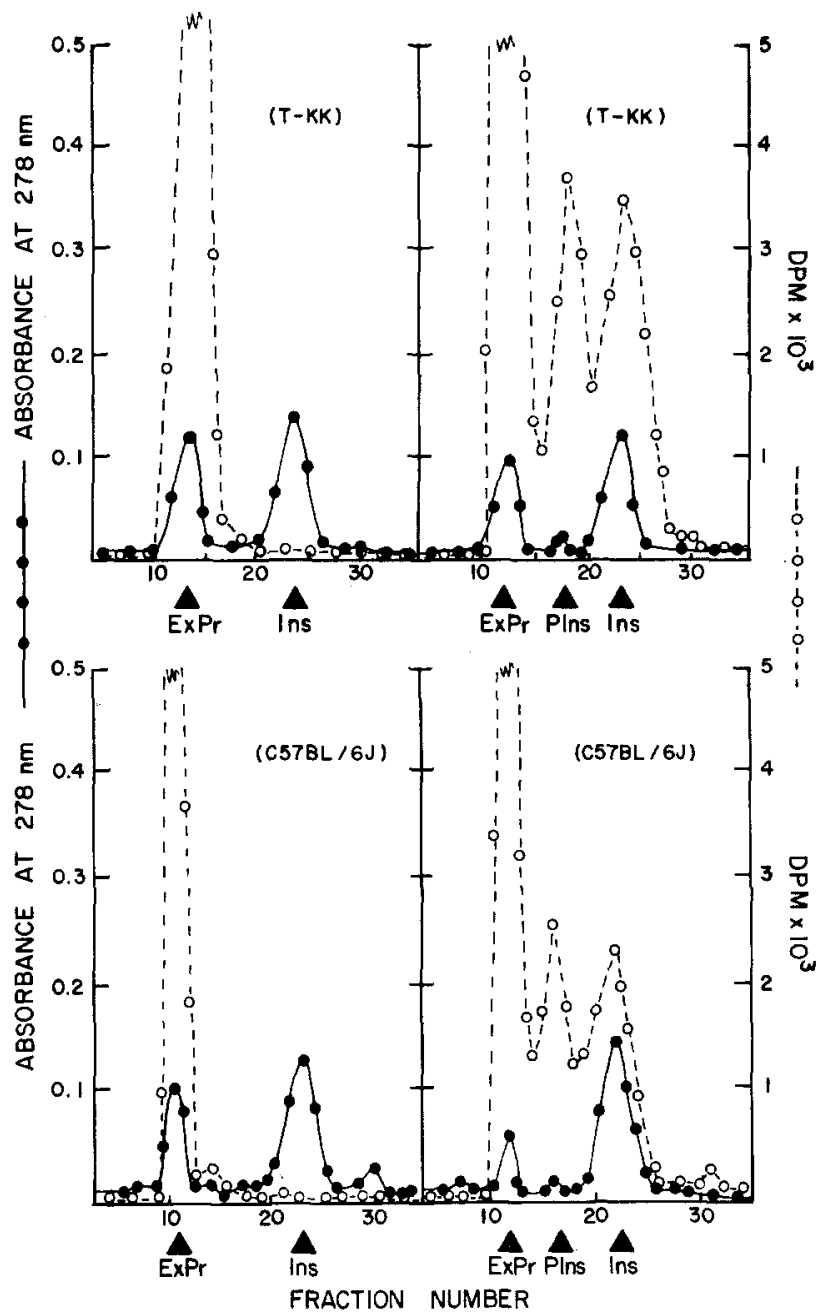

Fig. 5. BioGel P30 elution profile of acid alcohol extracts of islet and acinar tissues. - - - indicates absorbancy at $278 \mathrm{~nm}$. - $\mathrm{O}-\mathrm{O}-$ indicates incorporation of Leucine${ }^{3} \mathrm{H}$. ( $\mathrm{ExPr}=$ exclusion proteins; Ins $=$ insulin; PIns $=$ proinsulin)

ences were seen in the degrees of granulation of Toronto-KK islets during fasted and non-fasted dietary conditions (Fig. 7). Islets from non-fasted Toronto-KK mice showed pronounced depletion of B-granules, whereas non-fasted $\mathrm{C} 57 \mathrm{BL} / 6 \mathrm{~J}$ islets retained a full component of B-granules. 


\section{Discussion}

Since levels of blood glucose reflect the dynamic equilibrium between its utilization and production, one may infer that hyperglycemia in Toronto-KK mice results from a decreased utilization of glucose and/or an overproduction of glucose. Several investigators have observed glucose intolerance and diminished sensitivity by adipose and muscle tissues to insulin in the $\mathrm{KK}$ mouse $[7,16]$. Such evidence is strongly supportive of the notion that hyperglycemia in the Toronto-KK peritoneally administered pyruvate- ${ }^{14} \mathrm{C}$ to glucose- ${ }^{14} \mathrm{C}$ of whole blood, suggesting that gluconeogenesis is likewise elevated in vivo.

That hepatic gluconeogenesis is elevated in diabetic Toronto-KK mice is surprising from at least several points of view. Hepatic gluconeogenesis is normally more active during periods of starvation in an attempt to accomodate metabolic requirements. Hepatic gluconeogenic enzymes from Toronto-KK mice had increased activity during non-fasting dietary conditions despite the obese physical state of the animal. In addi-

Table 1. Comparison of islet insulin content and insulin release between six-month old Toronto-KK and $C 5 \% \mathrm{BL} / 6 \mathrm{~J}$ mice

\begin{tabular}{lllll}
\hline $\begin{array}{l}\text { Type } \\
\text { mouse }\end{array}$ & $\begin{array}{l}\text { Islet } \\
\text { insulin } \\
\text { non-perf.a } \\
(\mu \mathrm{U} / \text { islet) }\end{array}$ & $\begin{array}{l}\text { Islet } \\
\text { insulin } \\
\text { post-perf. } \\
(\mu \mathrm{U} / \text { islet })\end{array}$ & $\begin{array}{l}\text { Total insulin } \\
\text { released } \\
(\mu \mathrm{U} / 50 \text { islet } / \\
90 \mathrm{~min})\end{array}$ & $\begin{array}{l}\text { \% Islet } \\
\text { insulin } \\
\text { released }\end{array}$ \\
\hline C57BL/6J & $\begin{array}{l}2318 \pm 536^{\mathrm{c}} \\
(4)\end{array}$ & $\begin{array}{l}1760 \pm 578 \\
(4)\end{array}$ & $\begin{array}{l}6866 \pm 1944 \\
(5)\end{array}$ & $6.77 \pm 3.10$ \\
Toronto-KK & $4988 \pm 969$ & $4067 \pm 1105$ & $29556 \pm 13601$ & $14.00 \pm 2.95$ \\
& $(4)$ & $(4)$ & $(5)$ & $(4)$ \\
$(P)^{\mathrm{d}}$ & $<0.005$ & $<0.010$ & $<0.005$ & $<0.01$ \\
\hline
\end{tabular}

a Values were obtained using islets other than those used in perifusion studies. (Toronto-KK islet insulin content was determined from 25-100 islets per animal. C57BL/6J islet insulin content was determined from $35-50$ islets per animal.)

$\mathrm{b}$ Values were derived by the following expression: Insulin content per islet following $90 \mathrm{~min}$ of perifusion Insulin content per nonperifused islet

- Values represent means \pm S.D. Number of mice used are in parenthesis.

d $P$ is the probability for the difference between $\mathrm{C} 57 \mathrm{BL} / 6 \mathrm{~J}$ and Toronto-KK mice as determined by T-test.

Table 2. Comparison of islet characteristics and rates of incorporation of $\mathrm{KH}_{2} \mathrm{PO}_{4^{-}}{ }^{32} \mathrm{P}$ into $R N A$ fraction of isolated islets of Langerhans of $C 57 B L / 67$ and Toronto-KK mice

\begin{tabular}{|c|c|c|c|c|}
\hline Type mouse & $\begin{array}{l}\text { Islet DNA P P } \\
\text { (ngDNA } \mathrm{P} / \\
\text { islet) }\end{array}$ & $\begin{array}{l}\text { Islet RNA.P } \\
\text { (ngRNA } \mathrm{P} / \\
\text { islet) }\end{array}$ & $\begin{array}{l}\text { Total islet } \\
\text { incorp. } \\
\text { (dpm/ml/islet) }\end{array}$ & $\begin{array}{l}\text { Specific islet } \\
\text { incorp. } \\
\text { (pmole } / \mathrm{ml} / \mu \mathrm{g} \\
\mathrm{DNA} \cdot \mathrm{P} \text { ) }\end{array}$ \\
\hline C57BL/6J & $\begin{array}{l}2.4 \pm 0.3^{b} \\
(3)\end{array}$ & $\begin{array}{l}12.6 \pm 3.6 \\
(3)\end{array}$ & $\begin{array}{l}456 \pm 309 \\
(3)\end{array}$ & $\begin{array}{l}320 \pm 181 \\
(3)\end{array}$ \\
\hline Toronto-KK & $\begin{array}{l}6.9 \pm 0.6 \\
(3)\end{array}$ & $\begin{array}{l}56.9 \pm 37 \\
(3)\end{array}$ & $\begin{array}{l}2128 \pm 1210 \\
(3)\end{array}$ & $\begin{array}{l}809 \pm 232 \\
(3)\end{array}$ \\
\hline$P^{\mathrm{c}}$ & $<0.001$ & $<0.001$ & $<0.050$ & $<0.050$ \\
\hline
\end{tabular}

a Specific islet incorporation is defined as pmole of $\mathrm{KH}_{2} \mathrm{PO}_{4^{-3}}{ }^{32} \mathrm{P}$ incorporated per $m l$ RNA fraction per $\mu \mathrm{g}$ of islet DNA-P.

b Values represent means $\pm S$. D. Number of animals used are in parenthesis.

c $P$ is the probability for the difference between $\mathrm{C} 57 \mathrm{BL} / 6 \mathrm{~J}$ and Toronto-KK mice as determined from T-test.

mouse results from a decreased utilization of available glucose. The present studies also implicate overproduction of glucose as an additional etiological component of hyperglycemia in this animal. The elevated levels of gluconeogenic enzymes but normal levels of glucose catabolizing enzymes suggest that hepatic glucose production is accelerated in Toronto-KK mice. In addition, Wyse et al. [29] reported that Toronto-KK mice demonstrated an increased ability to convert intra- tion, insulin has been implicated to have an inductive effect on hepatic "regulatory" glycolytic enzymes and a suppressive effect on "regulatory" gluconeogenic enzymes [28]. Enzymes of livers from Toronto-KK mice, therefore, do not respond to insulin in the manner expected since elevated activities of hepatic "regulatory" gluconeogenic enzymes were coincident with exorbitantly increased levels of plasma immunoreactive insulin. 
Our data concerning the isolated pancreatic islets indicate that insulin biosynthesis and secretory mechanism within the B-cells of Toronto-KK mice are not impaired, but are hyperresponsive when stimulated by glucose. Supportive evidence for this notion is based on several experimental observations. Both Toronto$\mathrm{KK}$ and $\mathrm{C} 57 \mathrm{BL} / 6 \mathrm{~J}$ islets released minimal and essentially equal quantities of insulin in the absence of glucose. Therefore, insulin release from Toronto-KK islets does not proceed spontaneously and requires prior stimulation by those physiological agents directing normal insulin release. The biphasic patterns of insulin release and elution profiles of leucine- ${ }^{3} \mathrm{H}$ incorporation into acid alcohol-soluble proteins were qualitatively similar from islets of both animals. However, the extent of insulin release and of leucine- ${ }^{3} \mathrm{H}$ incorporation following glucose stimulation was much greater from Toronto-KK islets. It is therefore tempting to infer that insulin synthesis and release proceed in a similar manner in islets from both animals, but at an acceler-

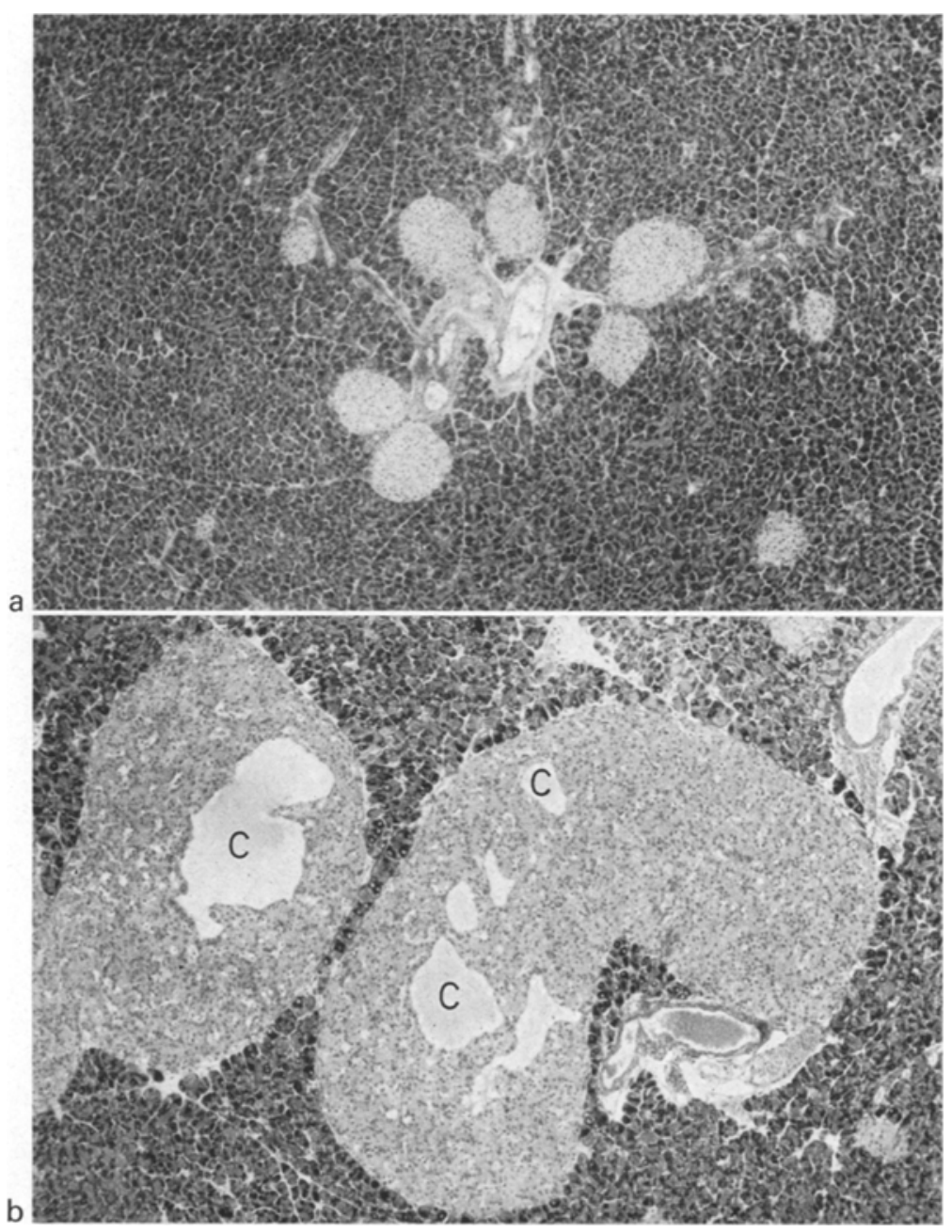

Fig. $6 \mathrm{a}$ and b. Pancreatic islets of six-month old C57BL/6J and Toronto-KK mice. a) C57BL/6J mouse (blood ghcose $105 \mathrm{mg} \%$, plasma immunoreactive insulin $41 \mu \mathrm{U} / \mathrm{ml}$ ). Hematoxylin and eosin stain $90 \times$. b) TorontoKK mouse (blood glucose $294 \mathrm{mg} \%$, plasma immunoreactive insulin $2560 \mu \mathrm{U} / \mathrm{ml}$ ). Islet demonstrates pronounced hyperplasia. Central cavitation (C) is apparent. Hematoxylin and eosin stain $90 \times$

Fig. 7a-c. Pancreatic islets of six-month old C57BL/6J and Toronto-KK mice during fasted and non-fasted dietary conditions. a) Small islet from a Toronto-KK mouse fasted for $24 \mathrm{~h}$ (blood glucose $85 \mathrm{mg} \%$, plasma immunoreactive insulin $81 \mu \mathrm{U} / \mathrm{ml}$ ). Islet appears deeply stained with well granulated aldehyde-fuchsin positive B-cells. Aldehyde fuchsin-ponceau stain $600 \times$ b) Small islet from a Toronto-KK mouse fod ad libitum (blood glucose $272 \mathrm{mg} \%$, plasma immunoreactive insulin $2560 \mu \mathrm{U} / \mathrm{ml}$ ). A small number of beta cells contain aldehyde fuchsin positive granules. Most beta cells are markedly degranulated (arrows). Aldehyde fuchsin-ponceau stain $600 \times$. c) Normal sized islet from a C57BL/6J mouse fed ad libitum (blood glucose $120 \mathrm{mg} \%$, plasma immunoreactive insulin $42 \mu \mathrm{U} / \mathrm{ml}$ ). Islet is well granulated. Aldehyde fuchsin-ponceau stain $600 \times$ 
ated rate in Toronto-KK islets. In addition, the similar incorporation patterns suggest that an abnormal conversion of proinsulin to insulin would not appear to be a factor in the elevated levels of plasma insulin observed from Toronto-KK mice.

The histologic appearance of pancreatic islets from

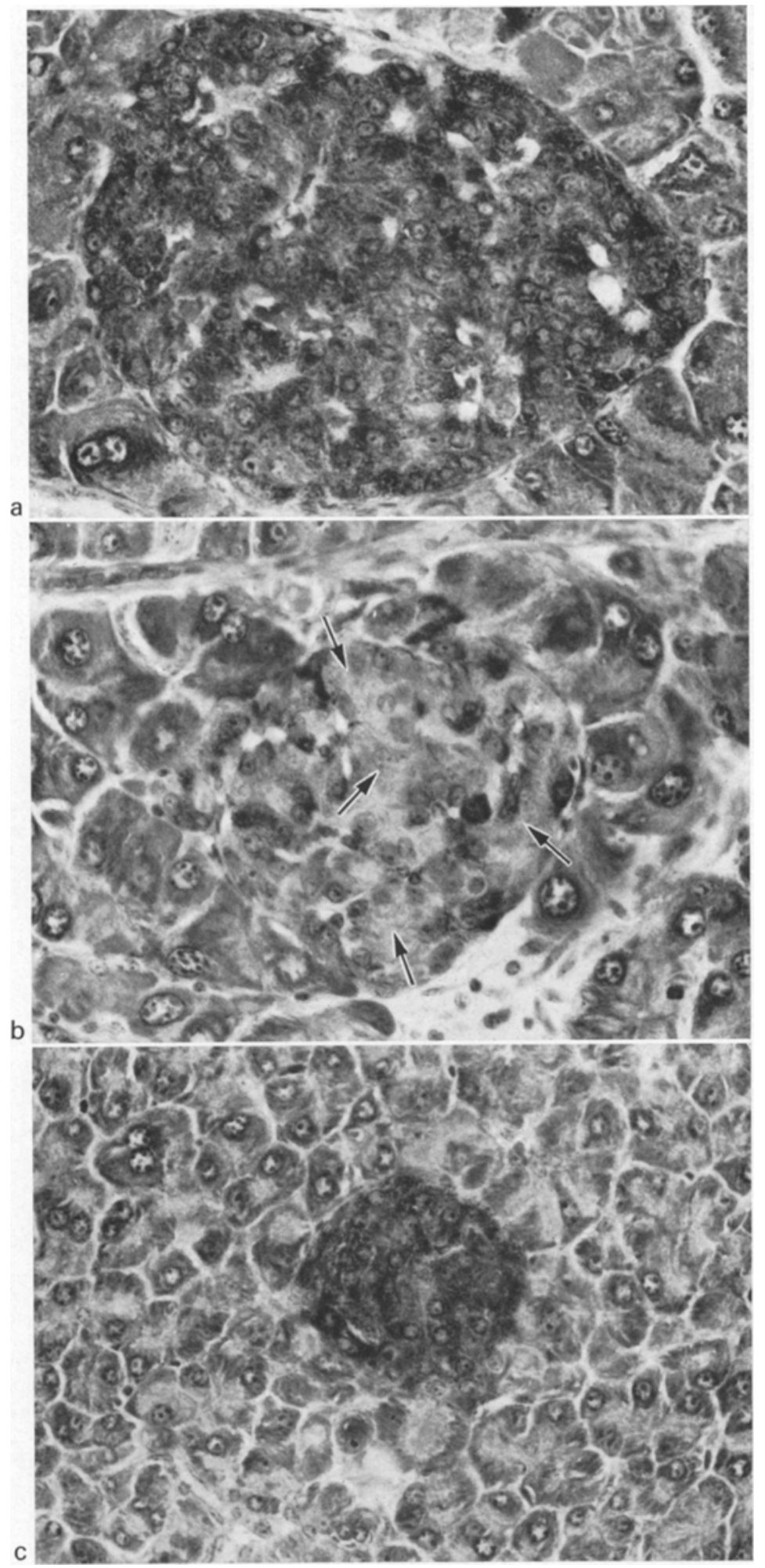

Fig. 7 
Toronto-KK mice during fasted and non-fasted dietary states was consistent with the above observations. The striking loss of aldehyde fuchsin positive granulation with feeding suggests that exaggerated quantities of insulin are released in response to appropriate nutrient stimulation. Thus hyperinsulinemia observed from nonfasted Toronto-KK mice probably reflects an accelerated rate of insulin synthesis and secretion from an increased volume of $\mathrm{B}$-cells, the absolute rate of secretion being, in part, dependent upon the insulin reserves contained within the islet.

The precise role of the islets of Langerhans in the diabetic syndrome of Toronto-KK mice remains unclear. The data indicate that hyperinsulinism in Toronto-KK mice is accompanied by hyperresponsive mechanisms of RNA and insulin biosynthesis and of insulin release. However, though rates of insulin biosynthetic and secretory activities are elevated, little is known concerning the causal effect of these processes on the observed B-cell hyperplasia. The specific causative factors ultimately responsible for this proliferation presently remain obscure.

In conclusion, our studies reveal that hyperglycemia appears to result, in part, from excessive and inappropriate hepatic gluconeogenesis. Hyperinsulinemia appears to result from excessive insulin biosynthesis and release from the pancreatic islets in response to glucose stimulation. This accelerated rate of insulin biosynthesis and release probably reflects both an increased volume of $\mathrm{B}$ cells and concomitant hyperrespondency displayed by these component $\mathbf{B}$ cells.

\section{References}

1. Appel, M.C.: Metabolic abnormalities in liver and pancreas of a diabetic (Toronto-KK) strain of mouse. Thesis, pp. 1-53, Western Michigan University 1973

2. Butler, L., Gerritsen, G.C.: A comparison of the modes of inheritance of diabetes in the Chinese hamster and the KK mouse. Diabetologia 6, 163-167 (1970)

3. Camerini-Davalos, R.A., Oppermann, W., Mittl, R., Ehrenreich, T.: Studies of vascular and other lesions in KK mice. Diabetologia 6, 324-329 (1970)

4. Chang, A.Y., Schneider, D.I.: Hepatic enzyme activities in streptozotocin-diabetic rats before and after insulin treatment. Diabetes 20, 71-77 (1971)

5. Davoren, P.R.: The isolation of insulin from a single cat pancreas. Biochim. biophys. Acta (Amst.) 63, $150-153(1962)$

6. Dubois, M., Gilles, K.A., Hamilton, J.K., Rebers, P.A., Smith, F.: Colorimetric method for determination of sugars and related substances. Analyt. Chem. $\mathbf{2 8}, 350-356(1956)$

7. Dulin, W.E., Wyse, B.M. : Diabetes in the KK mouse. Diabetologia 6, 317-323 (1970)

8. Dulin, W.E., Chang, A.Y., Gerritsen, G.C.: Comparison of diabetes in the Chinese hamster, KK mouse and $\mathrm{db}$ mouse. Excerpta Med. Proc. 7 th Cong. Internat. Diabetes Fed., Buenos Aires, pp. 868 - 880 (1970)

9. Fleck, A., Munro, H.N.: The precision of ultraviolet absorption measurements in the Schmidt-Thannhauser procedure for nucleic acid estimation. Biochim. biophys. Acta (Amst.) 55, 571-583 (1962)
10. Gerritsen, G.C., Dulin, W.E.: Characterization of diabetes in the Chinese hamster. Diabetologia 3, 7484 (1967)

11. Gomori, G.: Aldehyde fuchsin: A new stain for elastic tissue. Amer. J. clin. Path. 20, 665-666 (1950)

12. Grodsky, G.M., Bennett, L.L., Smith, D.F., Schmid, F.G.: Effect of pulse administration of glucose or glucagon on insulin secretion in vitro. Metabolism 16, $222-223(1967)$

13. Herberg, R.J.: Channels ratio method of quench correction in liquid scintillation counting. Packard Technical Bulletin No. 15 (1965)

14. Hoffman, W.S. : A rapid photoelectric method for the determination of glucose in blood and urine. J. biol. Chem. 120, $51-55(1937)$

15. Humasson, G.L.: Animal tissue techniques. P. 151. San Francisco: W.H. Freeman and Company 1962

16. Iwatsuka, H., Matsuo, T., Shino, A., Suzuoki, Z.: Metabolic disturbance of KK mice in chemical diabetes. J. Takeda Res. Lab. 29, 685-692 (1970)

17. Lacy, P.E., Kostianovsky, M.: Method for the isolation of intact islets of Langerhans from the rat pancreas. Diabetes 16, 35-39 (1967)

18. Lowry, O.H., Rosebrough, N.J., Farr, A.L., Randall, R.J.: Protein measurement with the Folin-phenol reagent. J. biol. Chem. 193, 265-275 (1951)

19. Matsuo, T., Iwatsuka, H., Suzuoki, Z.: Metabolic disturbance of KK mice in overt diabetes. Endocr. jap. 18, $501-506$ (1971)

20. Nakamura, M.: A diabetic strain of the mouse. Proc. jap. Acad. 38, 348-352 (1962)

21. Nakamura, M., Yamada, K.: Studies on a diabetic (KK) strain of mouse. Diabetologia 3, 212-221 (1967)

22. Nordlie, R.C., Snoke, R. E.: Regulation of liver microsomal inorganic pyrophosphate, glucose phosphotransferase, glucose-6-phosphatase and inorganic pyrophosphatase. Biochim. biophys. Acta (Amst.) 148, $222-232(1967)$

23. Sharma, C., Manjeshwar, R., Weinhouse, S.: Adenosine Triphosphate phosphotransferase of rat liver. J. biol. Chem. 238, 3840-3845 (1963)

24. Shonk, C. E., Boxer, G. E.: Enzyme patterns in human tissues. I. Methods for the determination of glycolytic enzymes. Cancer Res. 24, 709-721 (1964)

25. Tsanev, R., Markov, G.C.: Substances interfering with spectrophotometric estimation of nucleic acids and their elimination by the two-wavelength method. Biochim. biophys. Acta (Amst.) 42, 442-452 (1960)

26. Wagle, S.R., Ashmore, J.: Studies on carbon dioxide fixation in normal and alloxan-diabetic animals. Biochim. biophys. Acta (Amst.) 74, 564-565 (1963)

27. Weber, G., Cantero, A.: Fructose-1,6-diphosphatase and lactic dehydrogenase activity in hepatoma and in control human and animal tissue. Cancer Res. 19, $763-768$ (1959)

28. Weber, G., Singhal, R. L., Srivastava, S.K. : Action of glucocorticoid as inducer and insulin as suppressor of biosynthesis of hepatic gluconeogenic enzymes. Advances in Enzyme Regulation. 229-255. New York: Pergamon Press 1967

29. Wyse, B.M., Dulin, W.E.: Further characterization of diabetes-like abnormalities in the T-KK mouse. Diabetologia 10 (1974)

30. Zaharko, D.S., Beck, L.V.: Studies of a simplified plasma insulin immunoassay using cellulose powder. Diabetes 17, $444-457$ (1968)

Michael C. Appel

Dept. of Anatomy

University of Minnesota

Minneapolis, Minn. 55455

USA. 